\title{
ДОСЛІДЖЕННЯ ЕФЕКТИВНОСТІ ВИКОРИСТАННЯ СИСТЕМИ SMART FIRMER ЗА ВИРОЩУВАННЯ КУКУРУДЗИ НА ЗЕРНО
}

\author{
Зубко Владислав Миколайович \\ доктор технічних наук, доцент \\ Сумський національний аграрний університет \\ ORCID: 0000-0002-2426-2772 \\ vladislavzubko@ukr.net
}

Хворост Тетяна В'ячеславівна

кандидат економічних наук, доцент

Сумський національний аграрний університет

ORCID: 0000-0002-8863-8126

khvorost.t83@gmail.com
Литвиненко Єгор Євгенійович спеціаліст
Bueling
ORCID: 0000-0001-2312-7227
poisonnapalm@gmail.com

Серед великого різноманіття культур, що вирощуються на полях нині, значне місие посідає кукурудза. Поширення цієї культури зумовлене заявленою на неї кількістю готової сільськогосподарської продукції та ціною. Тому нині кукурудза є однією із передових сільськогосподарських культур, які вирощують у різних країнах і на континентах.

Одним із головних завдань процесу вирощування культур у сільському господарстві є якісний посів.

Нині все більш поширеними стають технології, які використовують усілякі датчики для контролю проведення сівби та посіву агрокультур.

У статті досліджено ефрективність використання системи Smart Firmer від компанії Precision Planting, який допомагає під час сівби визначити вологість ірунту, температуру, чистоту борозни та ї̈ однорідність.

Отже, досліджуючи проведення сівби кукурудзи на полях, головним фрактором має виступати якість проведення сівби, що забезпечує потребу обраного гібриду або сорту агрокультури відповідно до умов вирощування.

В умовах інтенсивної зміни грунтово-кліматичних умов актуальним науковим і прикладним завданням $є$ створення оптимальних умов для росту і розвитку агрокультур. Питання про моніторине середовища, в якому висіватиметься насіння, є важливим аспектом агровимог до проведення сівби агрокультур.

Нині слід зупинитися на визначенні і контролі вологи посівного шару, його температурі, наявності рослинних решток і визначенні типу грунту, на якому сіятиметься агрокультура.

Зафріксована температура в орному шарі грунту є критерієм проведення сівби, адже за температури нижче $10^{\circ} \mathrm{C}$ проводити посів не рекомендовано. Це пов'язано із втратою схожості насінини і подальшим загниванням посівного матеріалу.

Вологість грунту є показником, за яким регулюється глибина посіву агрокультури. Цей фрактор ураховують із метою отримання рівномірних сходів культури, незважаючи на рельєфь поля, зміну конфрігурації (приєднання до великого масиву полів дрібних фермерських із іншими попередниками та іншими типами обробітку).

Для цього потрібно врахувати наявну кількість рослинних решток агрокультури після попередників і тип грунту.

Ключові слова: сівба кукурудзи, вологість грунту, температура грунту, рослинні рештки, тип грунту.

DOI https://doi.org/10.32845/msnau.2021.3.3

\section{Постановка проблеми у загальному вигляді}

Агровиробництво в Україні $є$ однією із провідних галузей. Окрім стабільності у забезпеченні населення доступним та якісним продовольством, наше сільське господарство спроможне зробити вагомий внесок у вирішення проблеми світового голоду. Потенціал України у виробництві значно перевищує потреби на внутрішньому ринку.

Сільськогосподарські території становлять 42 млн. гектарів, або $70 \%$ від загального земельного фонду України: 78,9 \% сільськогосподарських угідь $є$ орними землями і багаторічними насадженнями; 13,0 \% - пасовищами ; 8,4 \% - сіножатями.
Станом на 2021 рік українські виробники агропродукції постачають товар майже у 190 країн світу (Pavlenko, 2015).

Протягом останнього часу на території України спостерігається стрімке зростання посівних площ під такі культури, як кукурудза, соняшник, соя, рапс. На це впливає сприятливий клімат для вирощування зазначених агрокультур і ціноутворення, яке нині можна прослідкувати на ринку агропродукції (Kernasyk, 2019).

Кукурудза нині має значну перевагу, тому неможливо переоцінити її важливість як для фермерського господарства, так і для підприємства. Це стосується і для нашої країни загалом, адже наша економіка невід'ємно залежить від аграрного сектору. Кожен аграрій прагне досягти 
високої врожайності, із більшою ефективністю використати свої ресурси і можливості для досягнення цієї мети.

Посів кукурудзи має таке ж велике значення, як і збирання, тому важливо дотримуватись усіх необхідних правил і норм (Baranov, 2021).

Головними вимогами до посіву кукурудзи із максимальною ефективністю та подальшого збирання врожаю $€$ (Baranov, 2021):

- терміни посіву;

- глибина посіву;

- норми посіву;

- добрива тощо.

Аналіз основних досліджень і публікацій

Розвиток сільського господарства неможливий без використання сучасної техніки. Працівники аграрного сектору розуміють, що збільшення рентабельності їхніх господарств прямо залежить від внесків, тому треба переходити на більш ефективні та ресурсозберігаючі технології обробітку. Сівалки точного висіву для просапних культур і посівні комплекси дозволяють раціонально використовувати посівний матеріал і добрива, економити на паливно-мастильних матеріалах і робочій силі, тим самим підвищуючи якість і врожайність продукції (Bilinska, 2015, Podolyan, 2021).

Механічні сівалки відрізняються простою конструкцією і відносно невисокою ціною, але вони мають суттєвий недолік: через забивання дозуючого диску висів може бути неточним. Проте пневматичні сівалки (які $€$ значно дорожчими) мають більш стабільну точність висіву і також можуть висівати двійники. Нині фермери мають можливість використовувати сівалки з електричним приводом, які мають більший строк служби і найкращі показники висіву, можливість регулювання норми висіву із кабіни та $€$ набагато простішими в обслуговуванні (Smolinskyi, S.).

Для якісного проведення посівної слід якісно до неї підготуватися: поле треба вирівняти, провести обробіток ґрунту, позбавитися бур'янів, обрати якісний посівний матеріал (Viniukov, O. et al., 2020). Та нині, крім цих базових факторів, якими керуються українські агрономи, із Америки прийшли нові рішення, більш націлені на методи точного землеробства: під час посіву особлива увага приділяється контролю за дотриманням норм висіву, розміщенню насінини, ширині міжрядь та інтервалу між рослинами, відсутності двійників, пересівів і пропусків.

Якість сівби забезпечує дружну схожість рослин, кращу густоту стояння і необхідну площу їх живлення. Така сівба можлива за застосування сівалок точного висіву, які є досить дорогими. Аграрію потрібно переконатися в доцільності фінансових інвестицій. Для цього проводяться дослідження, в яких розробники рішень підтверджують їхню ефективність.

Глибина розташування насіння.

Проростання насінини прямо залежить від стану ґрунту, його щільності, вологості і глибини, на якій розташована насінина. Важливим значенням для врожайності у майбутньому є добра схожість насіння, що залежить від сівалки та від того, чи може вона витримувати необхідне навантаження.

\section{Відстань між рослинами.}

У цих сівалках приділяється велика увага ефрективності розділення насіння, а також тому, з якої траєкторії насінина виходить, та вільному проходженню насіннєпроводом задля того, щоб траєкторія руху і доставка посівного матеріалу із бункера у ґрунт були однаковими.

Залежно від кліматичних умов і забезпеченості вологою регіону для різних сортів обирають різні норми висіву для забезпечення площі живлення рослини, необхідної для її розвитку. Крім того, має значення, в якому стані знаходяться ґрунти, та їхня якість: кількість гумусу, структура, забезпеченість мікроелементами.

Особливості рельєфу поля і корисні елементи живлення можуть розташовуватися нерівномірно, що впливає на рівномірність висіву. Найкращу врожайність із такого поля можна отримати лише у разі застосування диференційованого висіву, який виконується згідно із картою-завданням.

Окрім того, що норма висіву $є$ одним із найважливіших показників, який впливає на врожайність, необґрунтоване перевищення норми висіву призводить до значних перевитрат посівного матеріалу і значно збільшує витрати на посівну кампанію.

Висівати зерно кукурудзи рекомендовано пунктиром, коли глибина міжряддя становить 70 сантиметрів. Важливо уникати загущення, оскільки пригнічується розвиток качана, значно підвищуються витрати вологи із ґрунту, посилюється конкуренція рослин за світло. Внаслідок цього фрормуються насінини значно меншого розміру, ніж зазвичай, а також термін збирання урожаю зміщується. Рослини ранньостиглих гібридів мають менші розміри, за цією причиною сіяти їх можна густіше. Крім густоти стояння рослин, слід звертати увагу на їхнє рівномірне розміщення. Для досягнення оптимального стояння рослин можна зменшити ширину міжряддя, але таке зменшення негативно впливає на формування зернини у качані (Bogner, 2021).

Precision Planting Smart Firmer (рис. 1) - сенсор, який визначає вміст органічної речовини у ґрунті під час посіву та автоматично змінює норму у режимі on-the-go. Додатково в тому ж самому режимі визначається рівень вологості та залишків під сошником, на основі чого формується карта із високою роздільною здатністю, що дозволяє відразу коригувати глибину висіву.

Завдяки Smart Firmer диференційований посів стає ще доступнішим, оскільки не потрібно окремо досліджувати поле і створювати карту завдань.

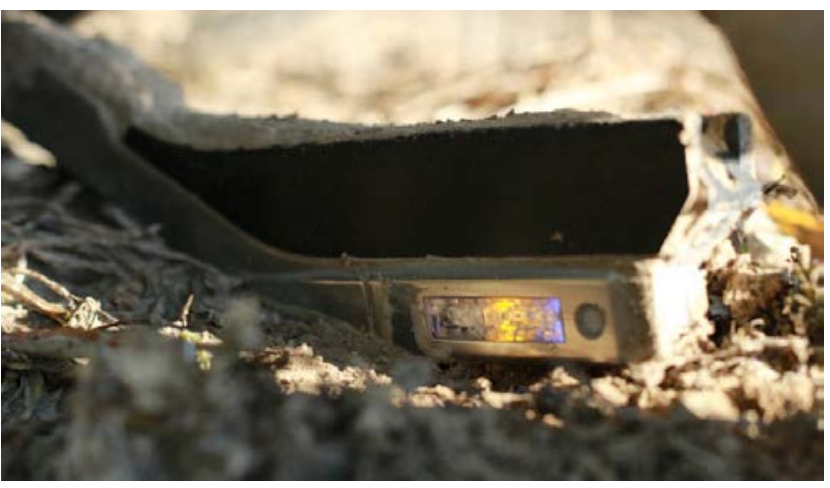

Рис. 1. Датчик Smart Firmer у польових умовах 


\section{Методика досліджень та обговорення результатів}

Основна мета - дослідження впливу появи дружних сходів кукурудзи на врожайність. Для контролю дати появи сходів використовувався "метод прапорців" (рис. 2). Коли рослина починала з'являтися над поверхнею землі, біля неї встановлювали прапорець. Для позначення періоду сходів рослин використовували прапорці чотирьох різних кольорів.

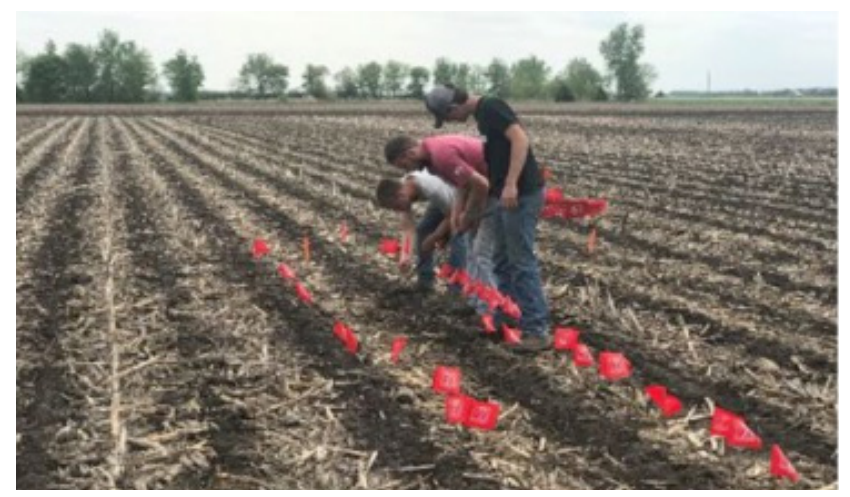

Рис. 2. Контроль дати появи сходів із використанням "методу прапорців"

На рис. 2 представлена нерівномірність сходів рослин, що позначено різнокольоровими прапорцями.

\section{Вимірювання температури ґрунту}

Дослідження, які проводили задля аналізу залежності інтенсивності сходів рослин від температури ґрунту показали, що температура має істотний вплив на появу сходів (рис. 3).

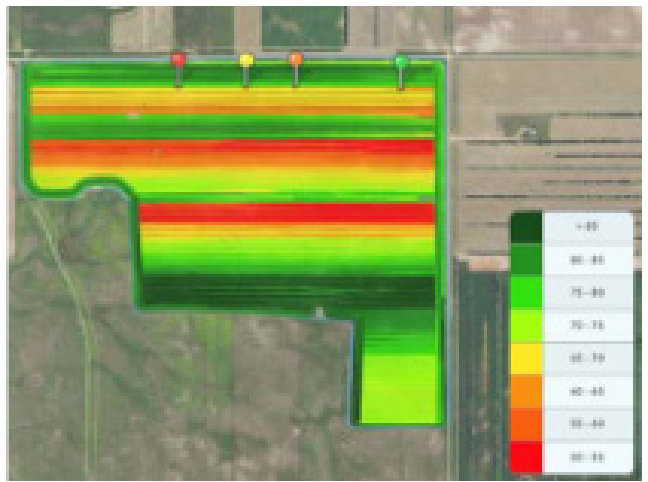

Рис. 3. Карта із визначеними ділянками поля за різних температур ґрунту

Достатня температура ґрунту є критичним компонентом для швидкої схожості насіння. Наприклад, тривалість проростання насіння кукурудзи різко зросте, якщо температура опуститься нижче $10^{\circ} \mathrm{C}$. Smart Firmer дає змогу встановити температуру ґрунту у посівній борозні від ряду до ряду, гарантуючи, що здійснюється посів у сприятливих умовах.

Однорідність борозни

Дослідження, які проводили для аналізу залежності інтенсивності сходів рослин від однорідності ґрунту, показали, що цей показник істотно впливає на появу сходів (рис. 4).

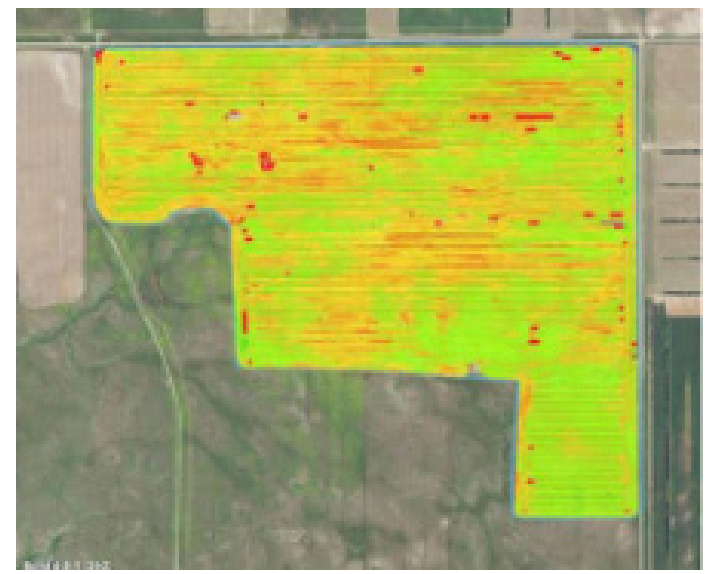

\section{Рис. 4. Карта із визначеними ділянками посіву} за різної однорідності ґрунту

Для однорідного проростання насіння та якісного зростання рослин потрібне однорідне середовище. Smart Firmer ідентифікує будь-які нерівності вздовж борозни, такі як грудки ґрунту, повітряний режим або вологість ґрунту, тому ви можете отримати уявлення про те, як правильно відрегулювати продуктивність секції сівалки і вирішити проблеми, які вплинуть на врожайність.

Визначення частки пожнивних решток

Дослідження показують, що частка пожнивних решток на поверхні поля $є$ нерівномірною, оскільки наявний різний рівень урожайності та якість виконання попередніх механізованих технологічних операцій. На рис. 5 представлена схема розподілення решток на посівному ложі.

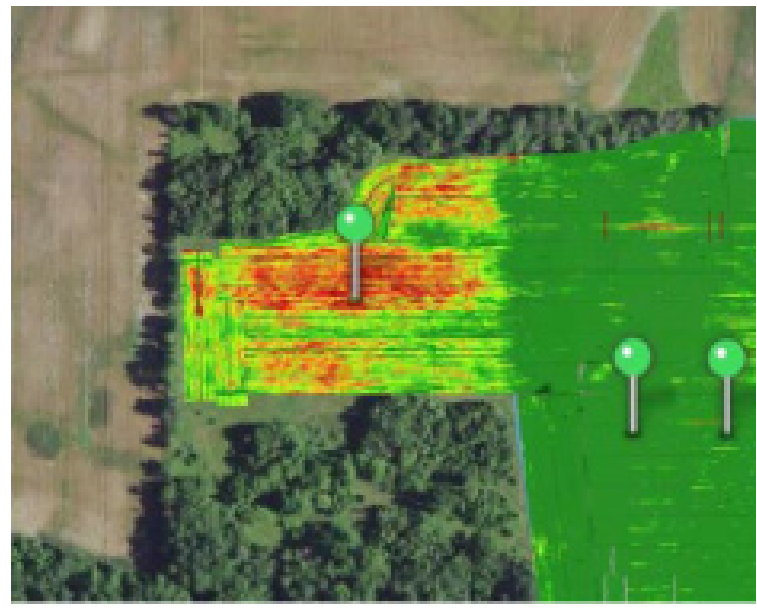

\section{Рис. 5. Рівень розподілення рослинних решток у посівному ложі}

Наявність пожнивних залишків у борозенці має добре відомі негативні наслідки для проростання насіння. Smart Firmer дозволяє вимірювати кількість залишків у борозенці і, відповідно, регулювати очисники рядів; це гарантує, що залишки не обмежуватимуть поглинання вологи насінням або їх заражати.

Визначення вмісту органіки

На рис. 6 представлена карта рівномірності розподілення органіки в межах одного поля. 


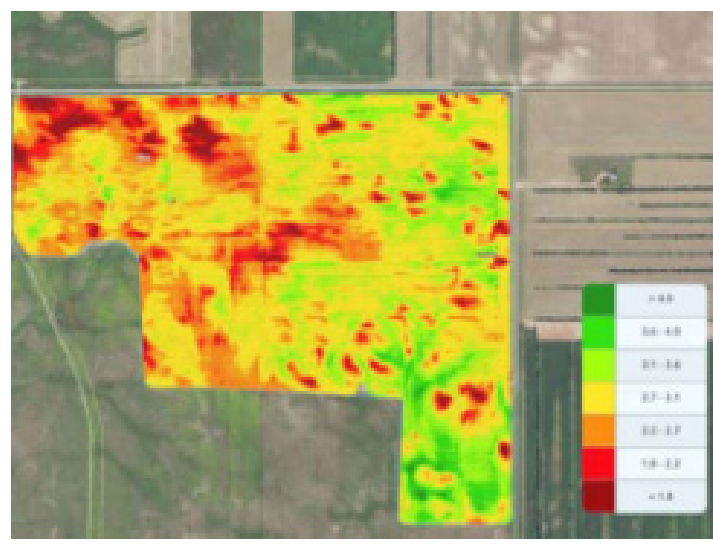

Рис. 6. Карта розподілення органіки в межах одного поля

На будь-якому полі врожайність залежить від чинників, які визначаються типом ґрунту, органічною речовиною, топографією, дренажем і безліччю інших чинників. Для кращого управління цими інструментами регулювання врожайності карта органічних речовин Smart Firmer високої чіткості $€$ ключовим фрактором для прийняття точних рішень під час вибору норм висіву, підбору гібридного насіння і програм із внесення добрив.

\section{Висновки:}

Проведеними дослідженнями встановлено, що тепло і вологість ґрунту - найважливіші чинники, на які слід зважати під час сівби задля досягнення швидкого і дружного проростання. Датчик Smart Firmer вимірює температуру ґрунту у режимі реального часу. Фермер має можливість прийняти ефрективне рішення щодо проведення посіву. Вміст вологи у ґрунтах різного типу може різнитись, але Smart Firmer фріксує і показує цю різницю, що дає змогу одразу трохи збільшити глибину посіву, щоб насіння потрапило у зону із достатньою вологістю. Механічна несправність висівної секції, наприклад погано закріплене опорне колесо, може призвести до закидання борозни сухим ґрунтом. Smart Firmer показує цей дефект під час сівби, і фермер може знайти та усунути несправності.

Унаслідок висихання ґрунту і зниження вмісту вологи у борозні глибину висіву доводиться збільшувати для того, щоб насіння надходило у досить вологий шар ґрунту. Навпаки, надто глибокий посів у борозну із достатньою кількістю вологи у ґрунті певних типів та агрегатної структури може призводити до затримування сходів.

Дослідження показують, що вологість ґрунту 30\% $€$ достатньою для набухання і проростання насіння більшості гібридів кукурудзи. Якщо вологість нижче 30\%, збільшують глибину посіву для того, щоб насіння потрапляло у вологіший ґрунт. Якщо вологість у борозні перевищує 30\%, глибину посіву збільшувати не потрібно; фактично така вологість може перешкоджати появі сходів. Для того, щоб повністю зрозуміти зв'язок між умістом вологи у борозні та глибиною посіву, потрібно здійснити додаткові дослідження.

Дослідження впливу якості посіву на врожайність кукурудзи, проведені у 2020-2021 роках в Україні
(Сумська область), показали, що рослини, які відставали від інших рослин у розвитку на один листовий комірець (вузол), у підсумку давали лише половину качана. Ті ж самі рослини, які відставали на два листових комірці, могли взагалі не дати врожаю.

Дослідження розташування насінин у ряду показали, що головний фактор впливу на точність розміщення - швидкість трактора. Якщо під час роботи на високій швидкості на висівні секції сівалки не забезпечувався оптимальний тиск, вони підскакують, а насіння рикошетить від стінок зернової трубки, що призводить до неточного розміщення насіння і порушення оптимальної відстані між рослинами. Додатковий імпульс сівалки може спричинити відбивання насіння від борозни, галопування і зайвий самостійний рух.

Нерівномірне розташування посівного матеріалу у борозні за однакових умов призводить до нерівномірності сходів. Для обчислення потенційних утрат врожаю внаслідок пізніх сходів качани перевіряли вручну. На рис.7 представлений розмір качанів рослин, які зійшли першими (протягом наступних 18 годин), а на рис. 8 - рослин, які зійшли через 42 години і більше після перших. Після визначення маси качанів під час збирання врожаю проведено розрахунки щодо затримки появи сходів. За важких погодних умов рослини, сходи яких з'являються найпізніше, можуть втратити до 50\% врожайності. Рослини, масові сходи яких з'являються через 18-28 годин після появи перших сходів, зазнають утрат на рівні $20 \%$, а через 29-42 години - 25\% (рис. 7 ).

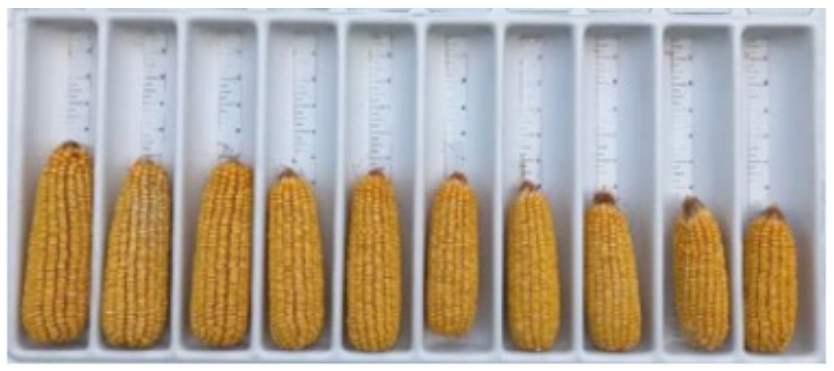

Рис 7. Розмір качанів у рослин, сходи яких з'явилися першими у наступні 18 годин

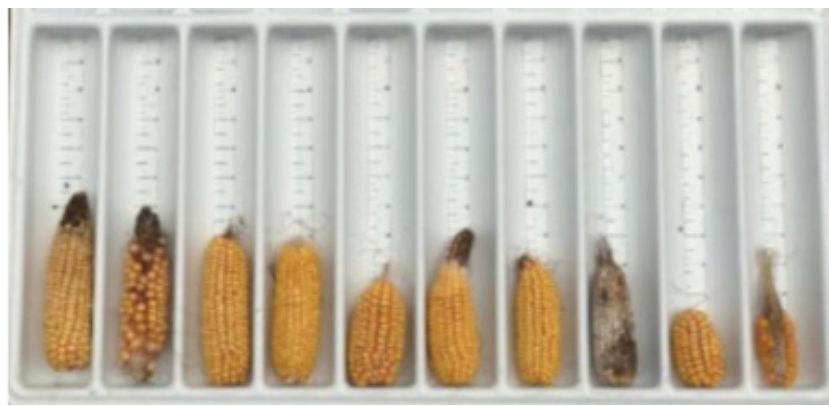

Рис. 8. Розмір качанів рослин, сходи яких з'явилися через 42 години і більше після перших

Проведеними дослідженнями встановлений вплив схожості зерна на врожайність посівів (рис. 9). 


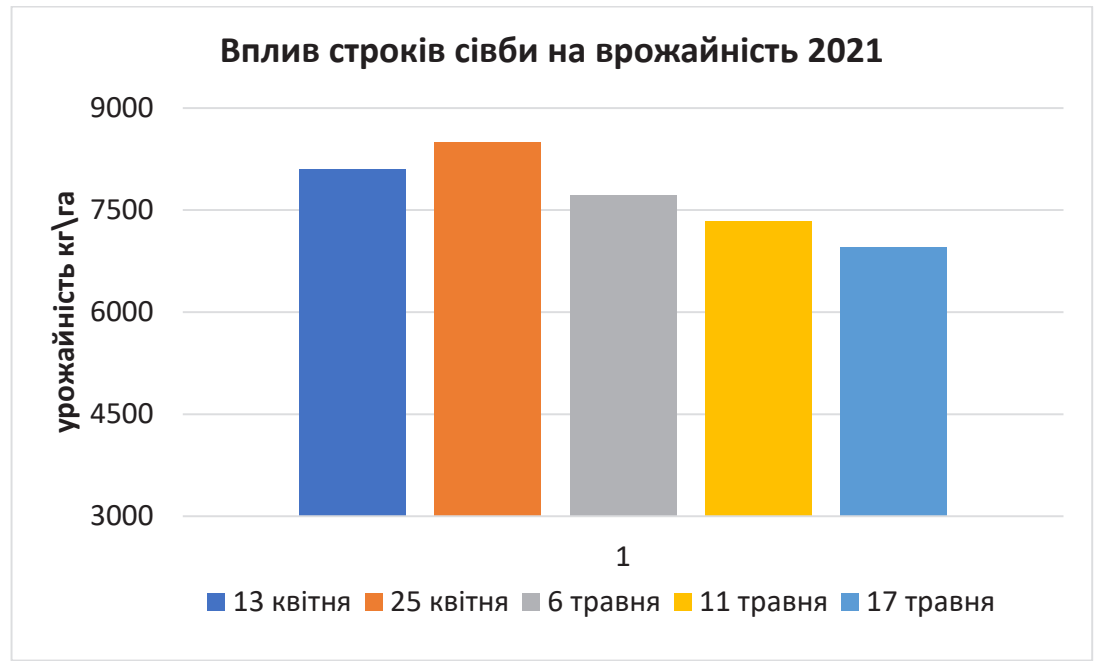

Рис. 9. Вплив строків сівби на врожайність

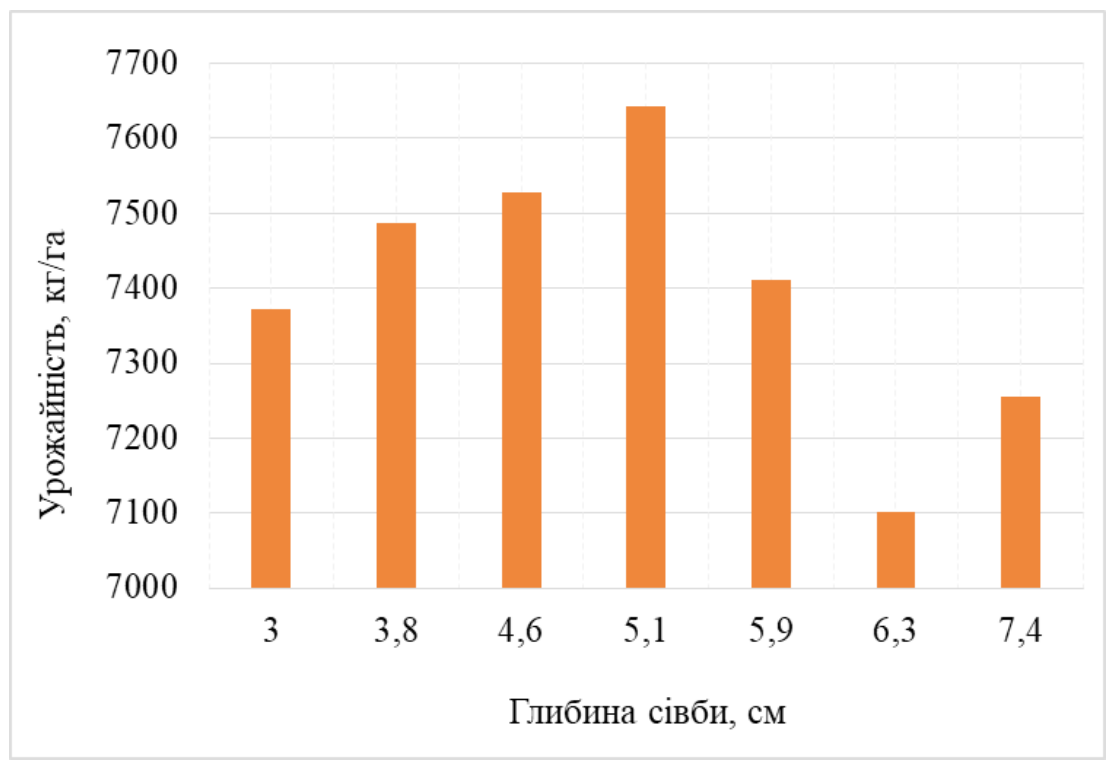

Рис. 10. Графік оптимальної глибини під час сівби

За даними рис. 9, найкращим періодом сівби кукурудзи був тиждень від 25-го квітня: кукурудза, посіяна того тижня, досягла найвищої врожайності. У межах цього дослідження врожайність становила 8492 кг/га (рис. 9).

Більш рання сівба (у тиждень від 13-го квітня) призвела до втрат урожайності приблизно на 400 кг/га через нижчу температуру і вищу вологість насіннєвого ложа.

Висів після оптимальної дати (25 квітня) призвів до зменшення врожайності на 710 кг/га.

Кукурудза, посіяна 17-го травня, дала найнижчу врожайність, її зниження перевищило 1544 кг/га.

Вологість ґрунту є важливим чинником проростання насіння і появи дружних сходів, досягнення максимальної врожайності. Датчики Smart Firmer надають нам показники вологості у кожній борозні, що дозволяє вибрати правильну глибину у разі зміни ґрунтових умов (рис. 10).

На основі проведених польових досліджень, результати яких представлено на рис. 10, доведено, що середня глибина посіву насіння становила 5 сантиметрів. Зменшення глибини висіву призводило до зменшення врожайності на 300-600 кг/га. Аналогічно, збільшення глибини висіву призводило до зменшення врожайності на 532-958 кг/га. У середньому економічні втрати становили \$50-100/га. Отже, ці показники підкреслюють важливість глибини посіву, показуючи, наскільки сильно відхилення від оптимальної глибини впливає на втрату врожайності та економічні втрати.

\section{Бібліографічні посилання:}

1. Pavlenko, A. (2015). Rekordnyiy eksport i rossiyskoe embargo: kakim zapomnili agrarii 2015 god [Record export and Russian embargo: how farmers remember 2015]. Kiev: Economic truth (in Russian). URL: https://epravda.com.ua/rus/ columns/2015/12/30/574660/ (reference date 01.09.2021). 
2. Kernasyk, Y. (2019). Oliini kultury: tendentsii na rynku [Oilseeds: market trends]. Kiev: Agribusiness Today (in Ukrainian). URL: http://agro-business.com.ua/agro/ekonomichnyi-hektar/item/15275-oliini-kultury-tendentsii-na-rynku.html (reference date 01.09.2021).

3. Baranov, D. (2021). Sivba kukurudzy: korysna informatsiia pro chas sivby, normu vysivu ta obrobitok gruntu [Sowing corn: useful information about sowing time, seeding rate and tillage]. KWS (in Ukrainian). URL: https://kws.com/ua/uk/ agroservis/sivba/sivba-kukurudzy/ (reference date 01.09.2021).

4. Bilinska, V. (2015). Suchasni innovatsiini tekhnolohii v silskomu hospodarstvi: osnovna kharakterystyka ta perspektyvy vprovadzhennia [Modern innovative technologies in agriculture: main characteristics and prospects of implementation]. Bulletin of Taras Shevchenko National University of Kyiv. Economics. Vol. 7 (172) p. $74-80$ (in Ukrainian).

5. Podolyan, A. (2021). Resheniya Precision Planting dlya poseva [Precision Planting solutions for seeding]. Kiev: Amaco (in Russian). URL: https://amacoint.com/ua/selhoztehnik/precision-seeding/ (reference date 01.09.2021).

6. Smolinskyi, S., Smolinska, A., Marchenko, V. (2017). Mekhanichni chy pnevmatychni sivalky - yaki lipshi? [Mechanical or pneumatic drills - which is better?]. Kiev: Agroexpert. URL: https://agroexpert.ua/mehanicni-ci-pnevmaticni-sivalki-akilipsi/ (reference date 01.09.2021).

7. Viniukov, O.O., Chuhrii, H.A., Bondareva, O.B. (2020). Naukovo-praktychni rekomendatsii po provedenniu kompleksu vesniano-polovykh robit $v$ donetskii oblasti [Scientific and practical recommendations for a set of spring field works in the Donetsk region]. Donetsk: Donetsk State Agricultural Research Station National Academy of Agrarian Sciences. 61 p. (in Ukrainian).

8. Bogner, B. (2021). Brendan enhanced his ExactEmerge with FurrowForce and vApply. URL: https://www. precisionplanting.com/products/testimonial/enhancing-a-new-planter-for-improved-emergence (reference date 01.09.2021).

Zubko V. M., Doctor of Technical Sciences, Associate Professor, Sumy National Agrarian University Sumy, Ukraine

Khvorost T. V., Candidate of Economic Sciences, Associate Professor, Sumy National Agrarian University Sumy, Ukraine

Litvinenko Y. Y., Specialist, Bueling, Kyiv, Ukraine

Research of efficiency of using the SmartFirmer system in growing corn on grain

Among the great variety of crops grown in the fields today, corn occupies a significant place. The spread of this crop is due to the declared quantities, both finished agricultural products and price. Therefore, today corn is becoming one of the leading crops grown in different countries and continents.

One of the main tasks of the process of growing crops in agriculture is quality sowing.

Today, technologies that use all sorts of sensors to monitor the sowing and sowing of crops are becoming more common.

The article examines the effectiveness of the SmartFirmer system from Precision Planting, which helps to determine soil moisture, temperature, furrow purity and homogeneity.

Thus, when researching the sowing of corn in the fields, the main factors should be the quality of sowing - meeting the needs of the selected hybrid or variety of agriculture in accordance with the conditions of cultivation.

In the conditions of intensive changes of soil and climatic conditions the actual science and applied tasks are creation of optimum conditions for growth and development of agricultural cultures. The issue of monitoring the environment where seeds will be sown is an important aspect of agricultural requirements for sowing crops.

Today we should focus on determining and controlling the moisture of the seed layer, its temperature, the presence of plant residues and determining the type of soil where sowing is carried out.

The fixed soil temperature in the seed layer is a criterion for sowing. After all, at temperatures below $10^{\circ} \mathrm{C}$ sowing is not recommended. This is due to the underdevelopment of the seed and the subsequent rot of the seed.

Soil moisture is an indicator that regulates the depth of sowing. This is in order to obtain uniform crop seedlings regardless of the terrain, changes in configurations (joining a large array of small farm fields with other predecessors and other types of cultivation).

To do this, it is necessary to take into account the available amount of crop residues after predecessors and soil type.

Key words: corn sowing, soil moisture, soil temperature, plant residues, soil type.

Дата надходження 23.08.2021 p. 